\title{
Nutrient composition and degradability of morphological fractions of two sweet potato (Ipomoea Batatas) varieties and the supplementary effect of their vine feeding on growth and carcass performances of grazing Arsi-bale lambs
}

\begin{abstract}
Nutrient content and in vitro dry matter degradability (IVDMD) of morphological fractions (stem, petiole, leaf) of two sweet potato varieties (Hawassi-83 and Tula) and supplementary effect of their vines on weight change and carcass traits of grazing local sheep was studied. Vine cuts of the two varieties were planted and grown for 150days on fields of four farmers. Samples of vine parts were taken at age of 35, 42 and 47 days after planting and analyzed for nutrient content. Five treatment diets were formulated $(\mathrm{G}=$ grazing alone, $\mathrm{GHV} 1=$ grazing $+103 \mathrm{~g}$ DM Hawassi -83 vine, GHV2= grazing $+206 \mathrm{~g}$ DM Hawassi- 83 vine, GTV1=grazing $+103 \mathrm{~g}$ DM Tula vine and GTV2=Grazing $+206 \mathrm{~g}$ DM Tula vine). Twenty yearling male Arsi-Bale lambs were purchased and blocked in to four and assigned to five treatment diets randomly. The daily vine supplement was wilted for $2 \frac{1}{2} \mathrm{~h}$ and sub-sample was taken daily and preserved in a refrigerator for chemical analysis. Feed intake was calculated daily and body weight gain weekly. Sheep were fed for 84 days and at the three sheep under each treatment were randomly selected and slaughtered for carcass analysis. Lowest DM $(\mathrm{p}<0.05)$ content in the three growth stages $\left(5^{\text {th }}, 6^{\text {th }}\right.$ and $\left.7^{\text {th }}\right)$ was from Fresh Tula Stem and Petiole (FTSP) but the highest $p<0.05)$ in Fresh Tula Leaf $(F T L)$. Lowest $(p<0.05)$ OM during the three sampling periods was in Fresh Tula Vine (FTV) but highest $(\mathrm{p}<0.05)$ in FTL. From pooled mixture, lowest $(\mathrm{p}<0.05)$ DM was in FTSP but highest $(\mathrm{p}<0.05)$ in FTL. Lowest $(\mathrm{p}<0.05)$ OM was in FTV but highest $(\mathrm{p}<0.05)$ in FTL. The lowest $(\mathrm{p}<0.05)$ crude protein (CP) content was in Fresh Hawassi-83 Stem and Petiole (FHSP) and highest $(p<0.05)$ in FTL. Highest $(p<0.05)$ IVDMD $\%$ was in FHSP and FTL but lowest $(p<0.05)$ was in FTSP. The lowest $(p<0.05)$ daily weight gain and dressing percentage (calculated as total carcass/slaughtering body weight) were recorded in sheep under G and highest $(\mathrm{p}<0.05)$ under GHV2 and GTV2. Higher level of supplements of both sweet potato varieties can favor better growth and carcass yield; however, the overall assessment revealed that using Hawassi-83 that gave better weight gain and dressing percentage is recommended as it is also the preference of the farmers in terms of higher tuber production.
\end{abstract}

Keywords: assessment, sweet potato varieties, morphological fraction, supplement, nutrient content, dressing, percentage
Volume 7 Issue 4 - 2017

\author{
Dinku Getu,' Tegene Negesse, ${ }^{2}$ Mohammed \\ Beyan $^{2}$ \\ 'Southern Agricultural Research Institute, Ethiopia \\ ${ }^{2}$ Hawassa University, School of Animal and Range Sciences, \\ Ethiopia
}

Correspondence: Tegene Negesse, Hawassa University, School of Animal and Range Sciences, P.O. Box 05, Hawassa, Ethiopia, Email tegenengss38@gmail.com

Received: November 30, 2016 | Published: September 07, 2017

\section{Introduction}

Ethiopia owns 55,027,280 cattle, 27,347,933 sheep, 28,163,332 goat, 1,963,010 horses, 6,953,077 donkeys, 356,087 mules, 1,098,312 camels, 51,350,738 poultry and 5,052,297 beehives/colonies. ${ }^{1}$ They contribute 15 to 17 percent of GDP and 35 to 49 percent of agricultural GDP, and 37 to 87 percent of the household incomes. ${ }^{2}$ Among livestock production constraints feed inadequacy in terms of quantity and quality ${ }^{3}$ is the leading one. The common feeds in Ethiopia such as crop residues and natural pasture are inherently low in $\mathrm{CP}$, digestibility and minerals which lower the production capacity and fertility potential of animals. ${ }^{4}$ In order to improve animal productivity which relay on these feed sources, supplementation with feeds such as sweet potato which is grown on farmers plot and is better in content of $\mathrm{CP}$ and IVDMD is of paramount importance.
Sweet potato (Ipomoea batatas L.) is an important traditional crop that is grown customarily by small-scale farmers mainly for household consumption. It is traditionally regarded as a 'poor man's' crop as it is typically grown and consumed by resource poor households. It gives satisfactory yields under adverse climatic and soil conditions with low or no external inputs. ${ }^{5-7}$ As consequences of high livestock population density and reduced grazing area, intensive animal production (confinement and supplementary feeding) is evolving in some areas of SNNPRS. ${ }^{8}$ From the report of SWAO, ${ }^{9}$ the land covered by sweet potato plantation has increased from 10 ha to 195 ha between 2002/03 to 2011/12 cropping seasons. The farming communities living in the District feed sweet potato vine and tuber to livestock throughout the year or during dry season (Personal communication). The objective of this study was thus to assess the nutrient content and supplementation effect of vines of two sweet potato varieties on weight gain and carcass characteristics of grazing sheep. 


\section{Material and methods}

\section{Experimental Site}

The experiment was conducted in Moricho-Negasha Kebele of Shebedino District close to the capital of the District, Leku. Leku is $6^{\circ} 52^{\prime} \mathrm{N}$ latititude and $38^{\circ} 27^{\circ} \mathrm{E}$ longitude and $27 \mathrm{~km}$ south of Hawassa.

\section{Experimental feed production and preparation}

Vine cuts of two sweet potato varieties namely Hawassi-83 and Tula were purchased for three sequential plantations. Vines were planted at 15 days interval on fields of pre- agreed 4 farmers'. The sweet potato was cultivated 3 times during growth period. The sweet potato vine was cut at $3-5 \mathrm{~cm}$ height from the ground and chopped to about $7 \mathrm{~cm}$ and then sun-dried for $2 \frac{1}{2} \mathrm{hrs}$ (between $1: 00 \mathrm{pm}$ and $3: 30 \mathrm{pm})$

Table I Experimental design of the feeding trial

\section{Feed ingredients}

$\begin{array}{lll}\text { Treatment Groups } & \text { Grazing } & \text { Salt (5g/head/d) } \\ \text { G } & \sqrt{ } & \sqrt{ } \\ \text { GHVI } & \sqrt{ } & \sqrt{ } \\ \text { GHV2 } & \sqrt{ } & \sqrt{ } \\ \text { GTVI } & \sqrt{ } & \sqrt{ } \\ \text { GTV2 } & \sqrt{ } & \sqrt{ }\end{array}$

$\begin{array}{ll}\begin{array}{l}\text { Hawassi-83 vine g DM/ } \\ \text { head/d }\end{array} & \text { Tula Vine g DM/head/d } \\ - & - \\ 103 & - \\ 206 & - \\ - & 103 \\ - & 206\end{array}$

$\mathrm{G}$, grazing alone; $\mathrm{HV}$, hawassi-83 Vine; TV, tula vine

\section{Chemical analysis}

Chemical analysis of feed samples was carried out in Animal Nutrition Laboratory at Hawassa University. Fresh and wilted samples morphological fractions of the two sweet potato varieties (vine, leaf and stem and petiole) harvested at three growths stages were dried in an oven at $650 \mathrm{C}$ for $48 \mathrm{~h}$ for chemical analysis. These samples were then ground separately in Thomas-Wiley Laboratory mill (Model 4) to pass through $1 \mathrm{~mm}$ sieve and stored in tightly closed plastic bag until analysis. During sample taking for chemical analysis, the three round cuts were pooled according to the weight ratio of each sample after grinding. Samples were analyzed for DM, OM, CP and EE according to AOAC. ${ }^{10}$ Nitrogen was determined using Kjeldahl procedure and $\mathrm{CP}$ was calculated as $\mathrm{N}^{*} 6.25$. Neutral detergent fiber (NDF) was determined by the method of Van Soest et al. ${ }^{11}$ where as acid detergent fiber (ADF) and acid detergent lignin (ADL) were determined according to Van Soest and Robertson ${ }^{12}$ using Ankom ${ }^{220}$ fiber analyzer (Ankom Technology ${ }^{\circledR}$, Macedon, NY, USA).

\section{In vitro dry matter digestibility}

The in vitro dry matter digestibility (IVDMD) of the pooled samples of the 3 round forage cuts was determined using the two stages in vitro Tilley and Terry procedure ${ }^{13}$ as modified by Van Soest and Robertson. ${ }^{12}$

\section{Carcass analysis}

At the end of feeding experiment, three sheep from each of the five treatments were randomly selected for carcass analysis. After $12 \mathrm{hrs}$ of fasting, all sheep were weighed to know the slaughter weight. The sheep were killed by cutting the jugular vein together with the Apparatus.

\section{Statistical analysis} weight gain or carcass parameters; eij=random error.

\section{Experimental animal management and feeding}

Twenty male Arsi-Bale sheep (6-12months old and 13.4$17.3 \mathrm{~kg}$ body weight) were purchased at local market. On arrival to experimental site, lambs were ear tagged, and treated for internal and external parasites. Pens were cleaned daily and lambs washed weekly. Lambs were grouped in to 4 blocks. To each of the four farmers the 5 treatment diets were allotted and the 5 lambs from each of the 4 blocks were then randomly assigned to each of the treatments per farmer. Before starting the growth experiment, experimental lambs were fed about $50 \%$ of wilted sweet potato vine (SPV) in separate pens for the first 11days to acclimatize them to the new feeding regime (Table 1 ), and then they were fed for 84days. The wilted vine was provided in separate feeding troughs to animals every day at $6: 00 \mathrm{pm}$ when returning from grazing. To all animals $5 \mathrm{gm}$ of common salt (sodium chloride) was provided every day at $6: 00 \mathrm{pm}$ by separate trough. The animals were supplied with clean water ad lib.

throat. The bodies were skinned; the heads and feet were removed; the carcass was eviscerated and the alimentary canals were cleaned after the removal of the digesta. Blood, head, and four feet with hooves, skin, all empty visceral organs and the hot carcasses were weighed. To measure the rib-eye muscle area, the carcass was cut vertically between the $12^{\text {th }}$ and $13^{\text {th }}$ ribs and measured by Leaf Area Digester

Data were subjected to descriptive statistics, analysis of variance (Univariate/multivariate measure) using SPSS Version 22. ${ }^{14}$ Means were compared at $p<0.05$ using Duncan's Multiple range tests. The model used for statistical analyses of DM or OM content of the morphological fractions of the two sweet potato varieties under three growth stages was: $Y i j=\mu+\alpha i+\Theta j+\alpha i \Theta j+e i j$; where: $Y i j=D M$ or $O M$ content of the vine, leaf and petiole of the two sweet potato varieties at three stage of maturity; $\mu=$ over all mean; $\alpha i=$ effect of morphological fractions of the sweet potato on DM or OM content; $\Theta \mathrm{j}=$ effect of stage of maturity on DM or OM content; $\alpha \mathrm{i} \Theta \mathrm{j}=$ interaction effect among the sweet potato fractions with stages of maturity of sweet potato on DM or OM content; eij=random error. The model used for statistical analyses of nutrient content of the morphological fractions of the two sweet potato varieties was: $Y i j=\mu+\alpha i+e i j$; where: $Y i j=$ nutrient content of the vine, leaf and petiole of the two sweet potato varieties; $\mu=$ over all mean; $\alpha \mathrm{i}=$ effect of morphological fractions of the sweet potato on nutrient content; eij=random error. The model used for statistical analyses of the feed intake, body weight change or carcass parameters was: $Y i j=\alpha+b i+e i j$; where: $Y i j=$ feed intake or weight gain or carcass parameters; $\alpha=$ overall mean/intercept; bi $=$ effect of treatment on 


\section{Results and discussion}

Growth stage effect on nutrient content of morphological fractions of sweet potatoes

The DM and OM content of the morphological fraction is depicted in Table 2. As the growth stage increases from $5^{\text {th }}$ to $7^{\text {th }}$ months, DM content of FHV, FHL and FTL increased except in FHSP. At 5months, least DM was in FTSP but largest in FTL. At 6 and 7months, DM was lowest in FHSP but largest was still in FTL Pooled samples from the three growth stages gave similar trend in DM content. In all the tree growth stages, the least OM was in FTV but largest in FTL.

\section{Nutrient content and in vitro dry matter digestibly of morphological fractions}

Pooled nutrient content of the two sweet potato morphological fractions is depicted in Table 3. Fresh Tula Stem and Petiole was the least in DM and OM but that of Fresh Tula Leaf (FTL) was the highest. Similarly, OM content of FTL was the highest but that of FTV was the least. The crude protein (CP) content of FHSP was the lowest but that of FTL the highest. The CP content of FHSP was the lowest and is comparable to earlier report. ${ }^{14}$ The $\mathrm{CP}$ content of leaves
(FHL and FTL) was higher than that of the vines of the two sweet potato varieties which agree with earlier reports, ${ }^{15-17}$ Woolfe $^{18}$ stated that green sweet potato leaf generally holds $20.9 \%$ CP on DM basis. The $\mathrm{FAO}^{19}$ report shows that $\mathrm{CP}$ content of the vine is greater than $\mathrm{CP}$ content of all morphological fractions.

The difference could be attributed to differences in soil type, the stage of maturity and sweet potato varieties. FHL, FTL and FTSP were similar and the least in EE but that of FTV was the highest. The highest EE value in FTV might have been contributed by the petiole because the average mass of petiole per plant is slightly greater than that of leaf per plant in Tula variety. Least NDF was observed in FTL but highest in FTSP. The NDF value of FTSP was comparable with the NDF value of sweet potato stem ${ }^{16}$ but disagreed with the result reported by Etela and $\mathrm{Oji}^{15}$ in which leaf blade had the highest amount of NDF. NDF content of Hawassi-83 was lower than that in this study but nearly agreed with FTL of Hawassi-83, FHL of Koka-12 and FTV of Belela. ${ }^{17}$ Least ADF was observed in FTL but highest in FTSP which disagrees with the ADF value of sweet potato stem reported. ${ }^{16}$ Hawassi-83 vine had higher ADF content than the results in this study but is nearly the same as that of FHV of Alaba and Damote, FHSP of Koka-12 and FTSP of Bereda and Belela. ${ }^{18}$

Table 2 Dry matter and organic matter contents of morphological fractions (vine, leaf and stem-petiole) of the two varieties (Hawassi-83 and Tula) cut at three stage of maturity

\begin{tabular}{|c|c|c|c|c|c|c|c|c|c|}
\hline \multirow{2}{*}{ Nutrients } & \multirow{2}{*}{ Growth stage } & \multicolumn{8}{|c|}{ Morphological fractions of sweet potato } \\
\hline & & FHV & FHL & FHSP & FTV & FTL & FTSP & SE & P-value \\
\hline \multirow{6}{*}{ DM, \% } & $I^{\text {st }}$ & $13.9^{\mathrm{aC}}$ & $15.8^{\mathrm{aD}}$ & $14.2^{\mathrm{C}}$ & $12.4^{\mathrm{aB}}$ & $18.8^{\mathrm{aE}}$ & $7.5^{\mathrm{aA}}$ & 0.171 & $P<0.05$ \\
\hline & $2^{\text {nd }}$ & $14.2^{\mathrm{bC}}$ & $16.2^{\mathrm{bD}}$ & $14.3^{\mathrm{C}}$ & $13.3^{\mathrm{bB}}$ & $19.0^{\mathrm{bE}}$ & $7.9^{\mathrm{aA}}$ & 0.071 & $P<0.05$ \\
\hline & $3^{\text {rd }}$ & $14.9 \mathrm{cD}$ & $16.8^{\mathrm{cE}}$ & $14.3^{\mathrm{C}}$ & $13.3^{\mathrm{bB}}$ & $19.1^{\mathrm{bF}}$ & $7.6^{\mathrm{bA}}$ & & $P<0.05$ \\
\hline & SEM & 0.047 & 0.058 & 0.033 & 0.064 & 0.033 & 0.039 & 0.067 & $P<0.05$ \\
\hline & $\mathrm{P}$-value & $P<0.05$ & $P<0.05$ & $p>0.05$ & $P<0.05$ & $P<0.05$ & $P<0.05$ & & $P<0.05$ \\
\hline & All & $14.3^{\mathrm{C}}$ & $16.3^{\mathrm{D}}$ & $14.3^{C}$ & $13.0^{\mathrm{B}}$ & $19.0^{\mathrm{E}}$ & $7.7^{\mathrm{A}}$ & 0.019 & $P<0.05$ \\
\hline \multirow{6}{*}{ OM, \%DM } & $\left.\right|^{\text {st }}$ & $86.3^{\mathrm{aC}}$ & $86^{\mathrm{bB}}$ & $86.2^{B}$ & $85.3^{\mathrm{aA}}$ & $91.5^{\mathrm{D}}$ & $86.4^{\mathrm{aC}}$ & 0.037 & $P<0.05$ \\
\hline & $2^{\text {nd }}$ & $87.2^{\mathrm{bD}}$ & $85.5^{\mathrm{aB}}$ & $86.3^{c}$ & $83.5^{\mathrm{aA}}$ & $91.3^{\mathrm{E}}$ & $85.3^{\mathrm{bB}}$ & 0.033 & $P<0.05$ \\
\hline & $3^{\text {rd }}$ & $86.9^{\mathrm{bE}}$ & $85.8^{\mathrm{abC}}$ & $86.3^{D}$ & $83.3^{\mathrm{bA}}$ & $91.3^{F}$ & $84.8^{\mathrm{cB}}$ & & $P<0.05$ \\
\hline & SEM & 0.058 & 0.058 & 0.033 & 0.047 & 0.058 & 0.058 & 0.041 & $P<0.05$ \\
\hline & $P$-value & $P<0.05$ & $P<0.05$ & $P>0.05$ & $P<0.05$ & $P>0.05$ & $P<0.05$ & & $P<0.05$ \\
\hline & All & $86.8^{E}$ & $85.8^{C}$ & $86.3^{\mathrm{D}}$ & $84.0^{\mathrm{A}}$ & $91.4^{\mathrm{F}}$ & $85.5^{\mathrm{B}}$ & 0.022 & $P<0.05$ \\
\hline
\end{tabular}

Column Mean Values (For Growth Stage) of sweet potato parts bearing different lower case superscripts and row mean values (For Morphological Fractions) bearing upper case superscripts are significantly different $(\mathrm{P}<0.05)$. FHV, fresh hawassi-83 vine; FHL, fresh hawassi-83 leaf; FHSP, fresh hawassi-83 stem and petiole; FTV, fresh tula vine; FTL, fresh tula leaf; FTSP, fresh tula stem and petiole; DM, dry matter; OM, organic matter; ${ }^{\text {st }}$, 5Months; $2^{\text {nd }}, 6$ Months; $3^{\text {rd }}, 7$ months

Table 3 Nutrient contents and in vitro dry matter digestibility (Mean \pm SE) pooled/bulked samples of morphological fraction

\begin{tabular}{|c|c|c|c|c|c|c|c|c|}
\hline \multicolumn{9}{|c|}{ Morphological fractions of sweet potato } \\
\hline Nutrient DM\% & FHV & FHL & FHSP & FTV & FTL & FTSP & SEM & $P$-value \\
\hline Dry matter (\%) & $14.4^{\mathrm{c}}$ & $16.3^{d}$ & $14.3^{b}$ & $13.0^{\mathrm{b}}$ & $18.9^{\mathrm{e}}$ & $7.70^{\mathrm{a}}$ & 0.027 & $P<0.05$ \\
\hline Organic matter & $86.7^{d}$ & $85.9^{\mathrm{bc}}$ & $86.2^{c}$ & $84.0^{\mathrm{a}}$ & $91.5^{\mathrm{e}}$ & $85.6^{\mathrm{b}}$ & 0.046 & $P<0.05$ \\
\hline Crude protein & $17.6^{c}$ & $24.3^{e}$ & $11.3^{\mathrm{a}}$ & $22.2^{d}$ & $26.9^{e}$ & $13.4^{\mathrm{b}}$ & 0.068 & $P<0.05$ \\
\hline Ether extract & $12.8^{\mathrm{d}}$ & $8.30^{\mathrm{a}}$ & $12.4^{\mathrm{c}}$ & $15.2^{\mathrm{e}}$ & $9.90^{\mathrm{a}}$ & $8.50^{\mathrm{a}}$ & $0.04 I$ & $P<0.05$ \\
\hline Neutral detergent fiber & $34.5^{c}$ & $31.1^{b}$ & $34.9^{d}$ & $35.0^{d}$ & $27.7^{\mathrm{a}}$ & $41.6^{\mathrm{e}}$ & 0.041 & $\mathrm{P}<0.05$ \\
\hline Acid detergent fiber & $20.7^{c}$ & $16.9^{\mathrm{b}}$ & $24.9^{e}$ & $21.6^{d}$ & $13.9^{\mathrm{a}}$ & $29.0 f$ & 0.041 & $P<0.05$ \\
\hline Acid detergent lignin & $17.0^{c}$ & $11.4^{\mathrm{b}}$ & $19.7 \mathrm{e}$ & $17.1^{\mathrm{c}}$ & $9.90^{\mathrm{a}}$ & $18.3^{d}$ & 0.029 & $P<0.05$ \\
\hline \multicolumn{9}{|l|}{ Digestibility (\% DM) } \\
\hline IVDMD & $80.9^{c}$ & $78.0^{\mathrm{b}}$ & $84.4^{\mathrm{e}}$ & $82.4^{\mathrm{d}}$ & $84.3^{e}$ & $77.0^{\mathrm{a}}$ & 0.037 & $P<0.05$ \\
\hline
\end{tabular}

Row mean values bearing different superscript letters significantly different ( $p<0.05)$; IVDMD: In Vitro Dry matter digestibility; FHV, fresh hawassi-83 vine; FHL, fresh hawassi-83 leaf; FHSP, fresh hawassi-83 stem and petiole; FTV, fresh tula vine; FTL, fresh tula leaf; FTSP, fresh tula stem and petiole

Citation: Getu D, Negesse T, Beyan M. Nutrient composition and degradability of morphological fractions of two sweet potato (Ipomoea Batatas) varieties and the supplementary effect of their vine feeding on growth and carcass performances of grazing Arsi-bale lambs. Adv Plants Agric Res. 20 I 7;7(4):35I-355. DOI: I0.15406/apar.2017.07.00265 
The least ADL was found in FTL but the highest in FHSP which agrees with ADL content of sweet potato stem reported. ${ }^{16}$ Any of the ADL contents do not agree with the results reported on sweet potato vines. ${ }^{19,20}$ The in-vitro DM digestibility (IVDMD) of FTSP was the least but that of FHSP and FTL were the highest. The higher CP and lower NDF, ADF and ADL contents in FTL favored higher IVDMD; but it is difficult to explain the higher IVDMD of FHSP as it has high ADL and low CP. Vines in both varieties were second to leaves in IVDMD and disagrees with earlier results reported. ${ }^{16}$ FHL with the highest DM and CP and lowest ADL contents had the highest IVDMD. The highest CP but lowest EE contents were found in both FHL and FTL (Table 3).

\section{Supplements and body weight change}

The daily amount of supplement offered to the lambs is presented in Table 4. The lambs under T2 and T4 received half of the amount offered to lambs under T3 and T5. Sheep on similar amount of DM offered during the entire experimental period gained similar weight. Non-supplemented lambs that were only on grazing natural pasture (G) gained smallest but those in GHV2 and GTV2 gained highest. Gain of lambs under GTV2 is comparable with GHV1 and GTV1. The differences in weight gain resulted from differences in DM and CP intakes. The gain of lambs fed GHV1 and GTV1 was nearly the same as earlier reports about sheep supplemented with vine to root (25:75 and that of GTV2 was nearly same as those fed with vine to root ratio of 50:50, ${ }^{21}$ (Table 4).

\section{Trend of weekly weight gain}

Trend of body weight (BW) development of sheep under the five feeding regimes is depicted in Figure 1. Sheep under all treatments had fast weight gain during the first 2-3weeks. GHV2 had almost continually gained BW throughout the experimental period, although the highest was between $4^{\text {th }}$ and $6^{\text {th }}$ week and had highest final BW followed by GTV2. During the early feeding period, GHV1 gained better than GTV1 but from $4^{\text {th }}$ week to $9^{\text {th }}$ week they were very close and then GTV1 regained more toward the end of the trial. With an added advantage of higher initial BW of the control (G), it has closely followed GHV1 till the middle of the study period but it was left behind later and had the lowest final BW. Sheep under GHV2 got pick weight gain between $4^{\text {th }}$ and $6^{\text {th }}$ weeks of feeding period. Because of the onset of the dry season the sheep under G and GTV1 experienced a minimizing trend in body weight gain from $6^{\text {th }}$ week of feeding onwards, possibly due to depletion of natural pasture that did not match the increasing nutrient demand of the growing sheep.

\section{Carcass traits, dressing percent and percentages of edible and non-edible offal}

Sheep under GHV2 feeding regime had significantly larger total carcass (TC) than those of G, GHV1, GTV1 and GTV2 (Table 5). Sheep under GHV1 and GHV2 hold greater weight of total edible organs (TEO) than sheep under the rest of the feeding regimes. Dressing percentage (DP) calculated on the basis of slaughtering body weight (SBW) was similar in GHV2 and GTV2 but significantly greater than sheep under G, GHV1 and GTV1. Carcass percentage at empty body weight of highland sheep was $52.3 \%{ }^{22}$ which is greater than the results in this study. Dressing percentages reported from earlier study on Menz and Horro sheep were $48.7 \pm 7$ and $48.7 \pm 6$, respectively, ${ }^{23}$ which is close to values of GHV2 and GTV2. In tropical sheep an increasing trend of DP with increasing age has been reported. ${ }^{24}$ The present study lies within the range of values reported in earlier studie ${ }^{25}$ where DP or the edible proportion of a meat animal lied between 350 to $600 \mathrm{~g} / \mathrm{kg}$, which of course differs from country to country. Lack of visible variation in dressing percentage could have been possibly due to re-infection of sheep with Fasciolla hepatica that must have affected digestibility and metabolism and reduced growth of the lambs (Table 5).

Table 4 Body weight change of the lambs fed two levels of vines from Hawassi-83 and Tula.

\begin{tabular}{llllllll}
\hline Feeding Regime & & & & & & & \\
\hline Parameters & G & GHVI & GHV2 & GTVI & GTV2 & & \\
\hline Supplement (g DM/head/d) & 0 & 103 & 206 & 103 & 206 & SEM & P-value \\
Initial body weight (kg/head) & 15.6 & 15.4 & 14.6 & 14.5 & 14.7 & & \\
Final body weight (kg/head) & 19.6 & 20.9 & 23.6 & 20.4 & 21.9 & & \\
Weight change (g/head/d) & $48 \mathrm{a}$ & $72 \mathrm{~b}$ & $106 \mathrm{c}$ & $72 \mathrm{~b}$ & $89 \mathrm{bc}$ & 6 & $\mathrm{P}<0.05$ \\
\hline
\end{tabular}

G, grazing; GHVI, grazing+103g DM hawassi-83 vine; GHV2, grazing+206g DM hawassi-83 vine; GTVI, grazing+ 103g DM tula vine; GTV2, grazing + 206g DM tula vine; DM, dry matter

Table 5 Carcass traits of sheep fed with different levels of vines of the two sweet potato varieties

\begin{tabular}{llllllll}
\hline Feeding Regime & & & & & & SEM & P-value \\
\hline Parameters & G & GHVI & GHV2 & GTVI & GTV2 & & \\
\hline SBW $(\mathrm{kg})$ & $21.6^{\mathrm{a}}$ & $22.2^{\mathrm{b}}$ & $23.8^{\mathrm{c}}$ & $21.9^{\mathrm{ab}}$ & $23.5^{\mathrm{c}}$ & 0.373 & $\mathrm{P}<0.05$ \\
TEO $(\mathrm{kg} / \mathrm{sheep})$ & $3.91^{\mathrm{a}}$ & $4.41^{\mathrm{b}}$ & $4.54^{\mathrm{b}}$ & $3.90^{\mathrm{a}}$ & $4.1^{\mathrm{a}}$ & 0.214 & $\mathrm{P}<0.05$ \\
TC $(\mathrm{kg} / \mathrm{sh}$ seep $)$ & $8.32^{\mathrm{a}}$ & $8.71^{\mathrm{ab}}$ & $10.7^{\mathrm{d}}$ & $8.44^{\mathrm{ab}}$ & $10.0^{\mathrm{c}}$ & 0.592 & $\mathrm{P}<0.05$ \\
DP $(. \%$ at SBW $)$ & $42.0^{\mathrm{a}}$ & $41.0^{\mathrm{ab}}$ & $45.0^{\mathrm{b}}$ & $42.0^{\mathrm{ab}}$ & $46.0^{\mathrm{b}}$ & 0.025 & $\mathrm{P}<0.05$
\end{tabular}

Row least square means bearing different superscript letters are significantly different. G, grazing; GHVI, grazing + 103g DM hawassi-83 vine; GHV2, grazing+206g DM hawassi-83 vine; GTVI, grazing+ 103g DM tula vine; GTV2, grazing+206gdm tula vine; TEO, total edible offal; TC, total carcass; DP, dressing percent; SBW, slaughtering body weight. 


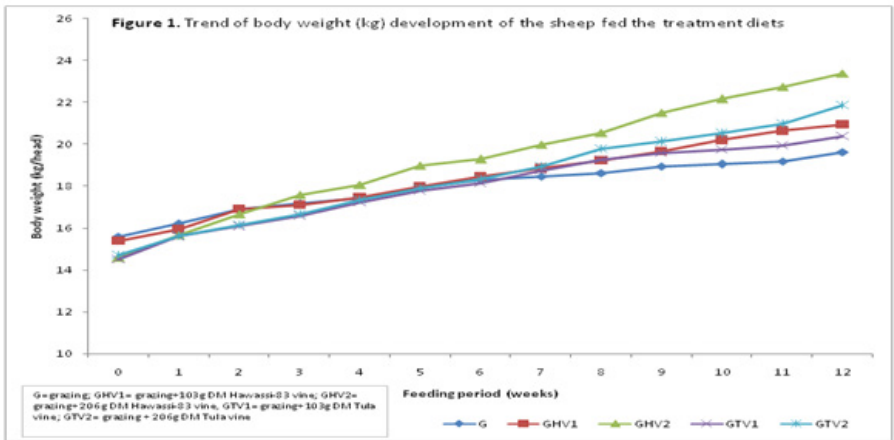

Figure I Trend of body weight $(\mathrm{kg})$ development of sheep fed the treatment diets.

\section{Conclusion and recommendation}

The DM\% of the morphological fraction of Tula variety was independent of the growth stage. FTSP was the least while FTL was the highest along the growth stage. Similarly, the OM was too. Least was in FTV but highest was in FTL. The more DM\% of pooled FHV with less CP\% and digestibility but more in EE than pooled FTV of the above contents at higher experimental level of this experiment gave better weight gain, dressing percentage and profit than FTV of the same higher experimental level in addition to farmer's preference on tuber production. For the sake of CP supplementation, using FHL, FTV and FTL as protein source over grains with lower CP contents is advantageous. Higher level of supplements of both sweet potato varieties can favor better growth and carcass yield; however, the overall assessment revealed that using Hawassi-83 that gave better weight gain and dressing percentage is recommended as it is also the preference of the farmers in terms of higher tuber production. ${ }^{26,27}$

\section{Acknowledgements}

We are grateful to International Potato Center (CIP) for funding the undertaking of the research.

\section{Conflict of interest}

The author declares no conflict of interest.

\section{References}

1. CSA (Central Statistical Agency) 2013/14 agricultural sample survey. Report on livestock and livestock characteristics. Addis Ababa, Ethiopia. 2008;2:5-188.

2. Gebre Mariam S, Amare S, Baker D, et al. Diagnostic study of live cattle and beef production and marketing. Ethiopian Agricultural Transformation Agency (ATA). 2010. p. 1-14.

3. Zinash S, Siyoum B, Luelseged G, et al. Effect of harvesting stage on yield and quality of natural pasture in the central high lands of Ethiopia; 1995

4. Solomon Gizaw, Azage Tegegne, Berhanu Gebremedhin, et al. Sheep and goat production and marketing systems in Ethiopia:Characteristics and strategies for improvement strategies. Ethiopia: International Livestock Research Institute (ILRI); 2011. p. 1-23.

5. Githunguri CM, Migwa YN. Performance of foliage and root yield of sweet potato clones from a preliminary yield trial at Kiboko in semi-arid eastern Kenya. In Annual report 2003. NHFRC-Katumani: Kenya: Kenya Agricultural Research Institute; 2004

6. Ndolo P J, Mcharo T, Carey E, et al. Participatory on-farm selection of sweet potato varieties in Western Kenya. African Crop Science. 2001;9(1):41-48.
7. Kung'u J N. Sweet potato production and consumption in major regions and selected countries in 1981/83; 1999.

8. CSA (Central Statistics Agency) The 2005/06 Ethiopian Agricultural sample enumeration (EASE), executive summary, April, 2007. Addis Ababa Ethiopia. 2007;5:1-40.

9. SWAO (Shebedino District Agricultural Office). The district basic information, Ethiopia; 2013.

10. AOAC (Official Methods of Analysis. Association of Official Analytical Chemists). In: K Helrick editor. 15th ed. Arlington; 1990. p. 1-1230.

11. Van Soest PJ, Robertson JB, Lewis BA. Method for detergent fiber, neutral detergent fiber and non-starch polysaccharidesin relation to animal nutrition. J Dairy Sci. 1991;74(10):3583-3597.

12. Van Soest PJ, Robertson JB. Analysis of forage and fibrous feeds. $A$ laboratory manual for animal science, 613. Department of Animal Sciences, USA: Cornell University; 1985. p. 1-202.

13. Tilley JMA, Terry RA. A two stage technique for In vitro digestion of forage crops. Journal of British Grass Land Society. 1963;18(2):104111.

14. SPSS (Software Package for Social Sciences) for windows Version 22; 2014.

15. Etela, U Oji. Variations in quality of whole-plant foliage components from sweet potato harvested at 12 and 20 weeks after planting; 2009.

16. Netsanet B. Sweet potato vines in small holder livestock feeding system and concentrate replacement value of sweet potato vines goat feeding. Dissertation, Ethiopia: University of Hawassa; 2006. p. 1-73.

17. Orodho BA, Alela BO, Wanambacha JW. Use of sweet potato (Ipomoea batatas L.Lam) vines as starter feed and partial milk replacer for calves; 1996.

18. Woolfe J. Sweet potato: untapped food resource. England: Cambridge University; 1992.

19. FAO (Food and Agricultural Organization of the United Nations). Tropical root and tuber crops. Rome: FAO plant production and protection paper; 1994. p. 1-133.

20. Tesfaye K, Amenti C. Effect of Variety and Plant Part on Chemical Composition of Sweet Potato (Ipomoea batatas l.) Vines Adami Tulu Agricultural Research Center. Ethiopia; 2008.

21. Tesfaye K, Tekalign G, Estifanos T. Performance and economic efficiency of browsing Arsi-Bale goats supplemented with sweet potato (Ipomoea batatas L.) vines as replacement for concentrate. International Journal of Livestock Production. 2011;2(7):92-99.

22. Dai Peters. Assessment of the potential of sweet potato as livestock feed in East Africa. A report presented to The International Potato Center (CIP) Kenya. 2008. p. 2-64.

23. Girma A, Kannan G, Goetsch AL. Effects of small ruminant species and origin (highland and lowland) and length of rest and feeding period on harvest measurements in Ethiopia. African Journal of Agricultural Research. 2010;5(9):834-847.

24. Enyew N, Rottmann OJ, Pirchner F, et al. Growth and carcass composition of tropical fat-tailed Menz and Horro sheep breeds. Animal Science. 2004;78(2):245-252.

25. Owen JE, Norman GA, Fisher IL, et al. Studies on the meat production characteristics of Botswana goats and sheep-Part I:Sampling, methods and materials, and measurements on the live animals. Meat science. 1997;1(1):63-85.

26. McDowell R E and Bove L. The goat as producer of meat. Report no. 60. USA: Cornell University; 1977.

27. Upton M. Farm Management in Africa: The Principle of Production and Planning. Great Britain: Oxford University Press; 1979;74(297):1-491.

Citation: Getu D, Negesse T, Beyan M. Nutrient composition and degradability of morphological fractions of two sweet potato (Ipomoea Batatas) varieties and the supplementary effect of their vine feeding on growth and carcass performances of grazing Arsi-bale lambs. Adv Plants Agric Res. 20I7;7(4):35I-355. 